\title{
THECAL CUP OF THE CRINOID EDRIOCRINUS PRESERVED INSIDE THE SHELL OF AN ORTHOCONE CEPHALOPOD: MIDDLE DEVONIAN, (EIFELIAN) FROM BOHEMIA
}

\author{
RUDOLF J. PROKOP \\ VOJTĚCH TUREK
}

National Museum, Department of Palaeontology, Václavské nám. 68, 11579 Praha 1, the Czech Republic; e-mail: rudolf.prokop@ seznam.cz; vojtech_turek@nm.cz

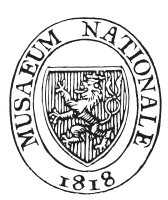

Prokop, J. R., Turek, V. (2014): Thecal cup of the crinoid Edriocrinus preserved inside the shell of an orthocone cephalopod: Middle Devonian, (Eifelian) from Bohemia. - Acta Mus. Nat. Pragae, Ser. B, Hist. Nat., 70(3-4): 219-222, Praha. ISSN 1804-6479.

Abstract. We describe an almost complete cup of the flexible crinoid genus Edriocrinus found in the Acanthopyge Limestone (Eifelian) in the Koněprusy region. The articulated cup, composed of an anal $\mathrm{X}$ and well defined radial plates, is preserved inside the living chamber of an orthocone cephalopod. This cup represents the stratigraphically youngest occurrence of the crinoid Edriocrinus in Bohemia.

Crinoidea, Edriocrinus, Middle Devonian, Eifelian, Bohemia.

Received November 3, 2014

Issued December 2014

\section{Introduction}

In 1994 Professor Ivo Chlupáč presented an unusual fossil specimen to the Palaeontological Department of the National Museum, Prague. It consists of a unique cup of the crinoid Edriocrinus sp. located inside the shell of an orthocone cephalopod.

The specimen is preserved in the white-grey bioclastic Acanthopyge Limestone that represents the shallow-water facies of the Choteč Formation (Eifelian) in the Koněprusy region. The almost complete calyx of Edriocrinus sp. found inside the damaged living chamber of an orthocone cephalopod was probably deposited there by sediment laden bottom currents in the dynamic environment of the Acanthopyge Limestone in the Koněprusy area. The crinoid may have been originally attached to the outer surface of cephalopod shell near the aperture and subsequently transported to its final position, inside the living chamber. This part of the shell frequently served as an attachment site for crinoid larvae in Palaeozoic seas (Turek 1983, Prokop and Turek 1987). Less frequently, crinoid larvae may have attached near the aperture on the inner surface of empty shells [also possibly the original location of the crinoid cup discussed herein] (Prokop and Petr 1995b) or to lobolites (bulbous float) of scyphocrinid crinoids (Strimple, 1997). Partial exfoliation of the cup's outer surface layer makes species determination of this crinoid impossible, so it is kept in open nomenclature.

The previous accepted stratigraphic range of the genus Edriocrinus in the Devonian of Bohemia was Pragian - Early Eifelian. The specimen described herein comes from the late Eifelian and is the youngest representative of the genus Edriocrinus in the Devonian of Bohemia. Outside the Czech Republic Edriocrinus occurs more frequently; e.g. in the Early Devonian beds of the USA (especially in the
Helderbergian $=$ Lochkovian), in the Early and Middle Devonian of Germany, Early Devonian of France and in the Early and ?Middle Devonian of Algeria (Moore 1978).

\section{Systematic part}

\author{
Subclass: Flexibilia ZITTEL, 1895 \\ Order: Uncertain
}

Family: Edriocrinidae S. A. MILler, 1889

Genus: Edriocrinus HALL, 1858

Type species: Edriocrinus pocilliformis HALL, 1859; SD Miller, 1889, Early Devonian, Helderbergian, the USA.

\section{Edriocrinus sp.}

$$
\text { Pl. 1, figs } 1-4
$$

M a t e r i a l: Almost complete calyx NM L 42444.

H o r i z o n: Acanthopyge Limestone, Choteč Formation, Eifelian, Middle Devonian.

L ocality: Koněprusy, abandoned quarry on the southern slope of Zadní Kobyla hill, in the lower layers of the Acanthopyge Limestone (4-5 $\mathrm{m}$ above the base), and in association with the goniatite Pinacites jugleri.

Description. Edriocrinus sp. is preserved as a broadly conical cup formed by five articulated, tall, slender radial plates, and anal X plate. Anal X in line with radials. Cup plates are partly exfoliated, radial facets straight, partly damaged. Basals flat, mostly obscured by sediment. Dimensions of the cup: Diameter of the upper border of cup $6 \mathrm{~mm}$, diameter of the cup base $15 \mathrm{~mm}$ and height of the exposed cup $11 \mathrm{~mm}$. 
Remarks. Edriocrinus sp. closely resembles the species Edriocrinus dispansus, KIRK (1911) from the Early Devonian of Tennessee, USA, which also has a broadly conical cup and possesses a broad flat base suitable for resting on soft substrate (without becoming mired), or for attachment to hard substrate, e.g. fragments of cephalopod shells, massive stems or bulbous float of crinoids etc. (Prokop 1976). We assume that the stemless crinoid discussed in this paper was cemented to the cephalopod shell. The cup is situated in the adapical part of the cephalopod living chamber close to the last formed septum. Here, we assume, water was relatively stagnated and poorly aerated. Therefore, we suggest that this specimen was transported inside the cephalopod shell by bottom currents, post-mortem.

\section{Appendix}

Stratigraphic occurrence and localities where cups or isolated skeletal remains of the crinoid genus Edriocrinus have been recorded in the Early and Middle Devonian of Bohemia:

\section{Lower Devonian, Pragian:}

Koněprusy Limestone. Massive white to light-grey sparitic bioclastic limestones.

- "Císařský lom" Quarry, "Zlatý kůn̆” hill near Koněprusy. Single specimen attached to the inner side of a Orthonychia gastropod conch (Prokop and Petr, 1995b).

- "Čertovy schody - West" Quarry, isolated RR, XX and basal parts of cups. Rare.

- "Na Plešivci" Quarry near Suchomasty, two basal parts of cup, one attached to the pluricolumnal and the second one attached to a shell fragment of an orthocone cephalopod. Isolated $\mathrm{RR}$ and $\mathrm{X}$ platelets.

Slivenec Limestone. Thick-bedded rosy to reddish sparitic crinoid limestones.

Isolated calycinal platelets in all localities and still accessible (localities see in Prokop, 2013). Rare.

Loděnice Limestone. Well-bedded platy variegated (rosy-grey-yellow) biosparitic and biomicritic limestones. Isolated calycinal platelets and complete or almost complete calyces are common at the same localities as Slivenec Limestone.

Dvorce-Prok op Limest on e. Well-bedded grey micritic limestone. Isolated platelets and calyces are common in all localities in the Barrandian Area, e.g.:

- Praha-Klukovice, “Červený lom” Quarry, eastern part.

- Praha-Hlubočepy, "St. Prokop" Quarries

- Praha-Smíchov, "Na Konvářce” section at the roadcut.

- Praha-Braník, "Branická skála” Quarry.

- Praha-Řeporyje, “U kantiny” Quarry.

\section{Zlíchovian (early Emsian):}

Zlíchov Limeston e. "Kaplička" Horizon at the base of the Zlíchovian Limestone. Massive to thick-bedded bioclastic limestones.
- Praha-Zlíchov, "U kapličky" Quarry. Two specimens consisting of basal parts of cup attached to crinoid remains. First is attached to the crinoid pluricolumnal, the second one to a fragment of a radicular holdfast. Isolated cup platelets abundant.

- Lochkov, “Hvížd’alka” Quarry. Isolated cup platelets, rare.

"Typical facies" of the Zlíchov Limestone. Well-bedded grey to dark-grey biodetritic to biomicritic limestones with cherts.

- Praha-Klukovice, “Červený lom” Quarry, eastern part, ca. $1 \mathrm{~m}$. above the "Kaplička Horizon. Isolated radials, rare.

\section{Dalejan (late Emsian):}

Tř e botov Limestone. Well-bedded light-grey micritic to biomicritic limestones.

- Praha-Holyně, "Prastav" Quarries. Common isolated calycinal platelets, complete or almost complete cups relatively rare.

- Praha-Hlubočepy, "U jezírka” Quarry. The same type of preservation as at the locality Praha-Holyně.

- Praha-Barrandov. Section at the roadcut of the highway. Abundant basals attached both to the crinoid stem fragments and to orthocone cephalopods. Abundant isolated cup platelets.

\section{Middle Devonian, early Eifelian:}

Choteč Limestone. Well-bedded grey and dark-grey fine grained bioclastic to micritic limestones.

- Praha-Holyně, "Prastav" Quarries. Isolated cup platelets. Rare.

- Praha-Barrandov. Section at the road cut of the highway. Abundant isolated cup platelets (Prokop and Petr 1995a).

Acanthopyge Limestone. Thick bedded, lightgrey to rosy-pink middle and coarse grained bioclastic limestones deposited in extreme shallow water on the tidal riff flat.

- Koněprusy, abandoned quarry on the southern slope of Zadní Kobyla hill. Single specimen, described herein.

\section{Acknowledgements}

We are indebted to Ronald Parsley (Tulane University, New Orleans) for linguistic improvement, Martin Valent and Lenka Váchová (National Museum, Prague) for technical help with the manuscript and to reviewers for their comments. The research was supported by the Ministry of Culture of the Czech Republic (grant no. DKRVO 2014/05, 00023272).

\section{References}

Kirk, E. (1911): The Structure and Relationships of certain Eleutherozoic Pelmatozoa. - U.S. National Museum Proceedings, 41: 1-137. http://dx.doi.org/10.5479/si.00963801.41-1846.1 
Moore, R. C. (1978): Flexibilia, Sagenocrinida. - In: More, R. C. and Teichert, C. (eds), Treatise on Invertebrate Paleontology, Part T, 2 (2), T 811-812. Geological Society of America and University of Kansas, Boulder and Lawrence.

Prokop, R. J. (1976): The genus Edriocrinus Hall, 1859 from the Devonian of Bohemia (Crinoidea). - Časopis pro mineralogii a geologii, 21(2): 187-191.

Prokop, R. J. (2013): Simakocrinus gen. nov. (Crinoidea, col.) from the Bohemian Early and Middle Devonian of the Barrandian Area (The Czech Republic). - Acta Musei Nationalis Pragae, Series B - Historia Naturalis, 69(1-2): 65-68. http://dx.doi.org/10.14446/AMNP.2013.065

Prokop, R. J., Petr, V. (1995a): New finds of isolated cup plates of the crinoid genus Edriocrinus in the Bohemian Lower and Middle Devonian. - Časopis Národního muzea, Řada př́rodovědná, 164(1-4): 49-50.

Prokop, R. J., Petr, V. (1995b): Edriocrinus cf. ata Prokop, 1976 (Crinoidea) from the Koněprusy Limestone of the Bohemian Lower Devonian attached inside a platyceratid shell. - Časopis Národního muzea, Řada prrírodovědná, 164(1-4): 105-106.

Prokop, R. J., Turek, V. (1987): Unikátní nález silurských flexibilních krinoidů přisedlých na schránku orthokonního nautiloida. A unique discovery of Silurian flexible crinoids attached to an orthocone nautiloid shell. - Časopis Národního muzea, Řada př́rodovědná, 152(4): 181-186.

Strimple, H. L. (1997): Possible comensal relationships between Edriocrinus and bulbous float of Scyphocrinites (Crinoidea, Echinodermata). - Oklahoma Geology Notes, 37(5): 171-173.

Turek, V. (1983): Hydrodynamic condition of the benthic community of upper Wenlockian calcareous shales in the western part of the Barrandian (Kosov quarry). - Časopis pro Mineralogii a Geologii, 28(3): 245-260.

\section{Explanation of the plate}

\section{PLATE 1}

Edriocrinus sp.

Middle Devonian, Eifelian, Acanthopyge Limestone. Koněprusy, abandoned quarry on the southern slope of the Zadní Kobyla hill.

1. Incomplete shell of the orthocone cephalopod with damaged cup of Edriocrinus sp. in its living chamber. Not whitened.

2. Fragment of counterpart, external mold of three connected radial plates from the cup. Not whitened.

3. Fragment of the orthocone cephalopod with cup of Edriocrinus sp. in oral view. Massive radial plates are partly exfoliated. Whitened with ammonium chloride.

4. The same specimen, lateral view. Whitened with ammonium chloride.

All scale bars $5 \mathrm{~mm}$.

The specimen NM L 42444 is deposited in the collections of the Palaeontological Department of the National Museum, Prague (abbrev. NM, catalogue L). Photos Lenka Váchová and Vojtěch Turek. 
PLATE 1

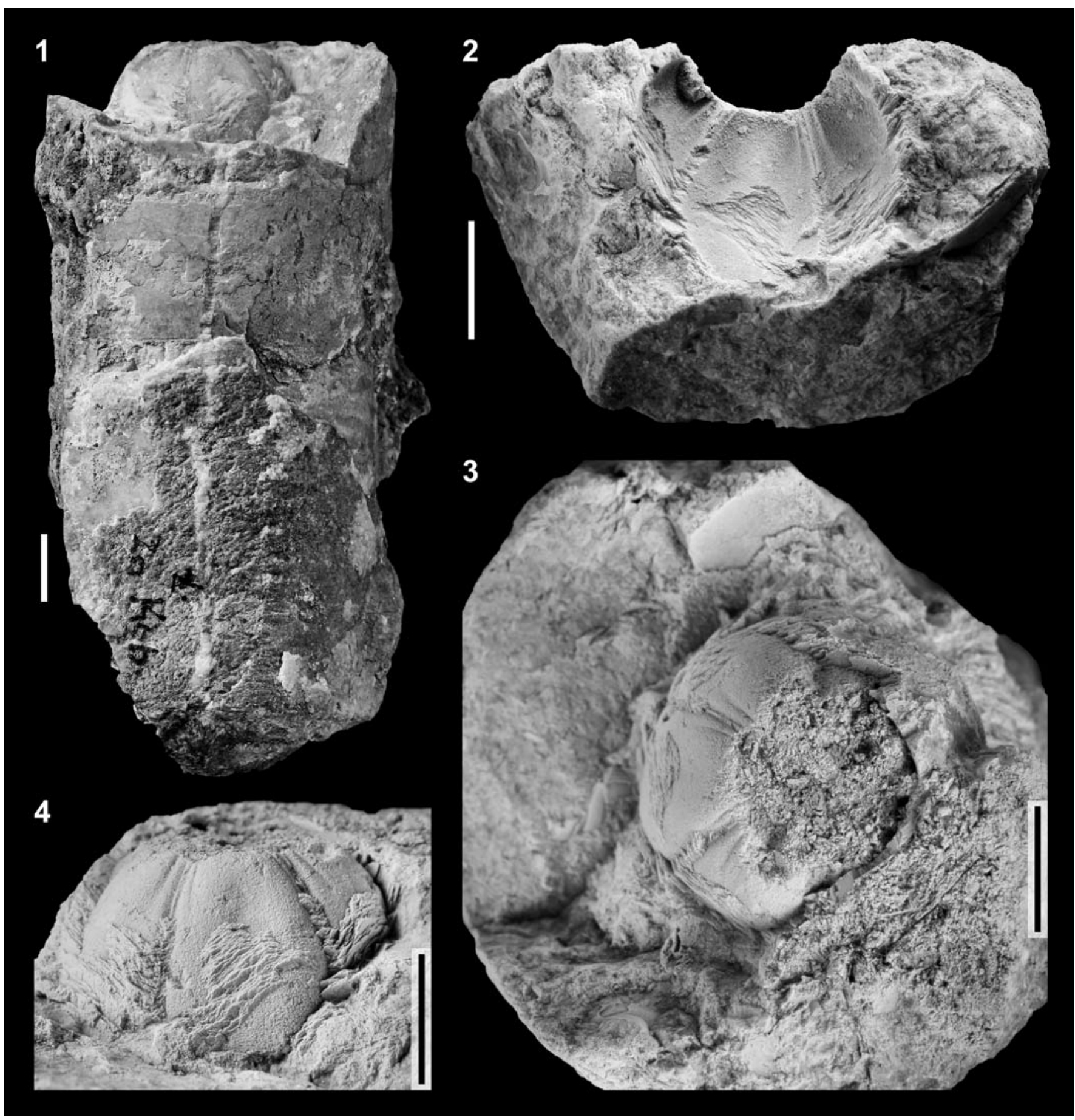

